\title{
The Legal Reform of Venture Capital Financing Institutions As a Financing Alternative for Micro Small and Medium Enterprises
}

\author{
Tri Setiady
}

Universitas Wiralodara, Indonesia, Email:trisetiady87@gmail.com

Submitted: April 30, 2020; Reviewed: July 2, 2020; Accepted: October 8, 2020

\begin{tabular}{|c|c|}
\hline Article Info & Abstract \\
\hline Keywords: & So far, the role of venture capital has not been \\
\hline Venture Capital, & optimal, or it can be said that while it is not working. \\
\hline $\begin{array}{l}\text { Financing, Micro, Small and } \\
\text { Medium Enterprises }\end{array}$ & $\begin{array}{l}\text { In practice, in Indonesia, venture capital companies } \\
\text { carry out their business like banking. That until now, } \\
\text { in oeneral venture canital }\end{array}$ \\
\hline DOI: & as credit providers as the usual practice of providing \\
\hline 10.25041/fiatjustisia.v15no1.1969 & $\begin{array}{l}\text { bank loans. All requirements and conditions } \\
\text { requested for a business partner company (actually: } \\
\text { a debtor) are like a bank in giving credit. Therefore } \\
\text { a legal reform of venture capital financing } \\
\text { institutions is needed to optimize financing for } \\
\text { micro, small, and medium enterprises to realize } \\
\text { national development. }\end{array}$ \\
\hline
\end{tabular}

\section{A. Introduction}

Funding institutions are believed to be one way to overcome the problems of companies that do not have sufficient assets as collateral for the proposed bank loans. Funding institutions are one form of business in the field of nonbank financial institutions that have a vital role in financing. The activities of the financial institution are carried out in the form of providing funds or capital goods that are not attractive directly from the public in the form of demand deposits, deposits, savings, and promissory notes. Based on the activities carried out by the funding agency, it has an essential role as one of the potential alternative funding sources to support the growth of the national economy. ${ }^{1}$

Funding institutions are said to be important because whoever they are, whether personal or a particular business entity, need funds to meet their needs. Funding needs for the business sector, especially for small businesses,

\footnotetext{
${ }^{1}$ Sunaryo, Lembaga Hukum Pembiayaan (Jakarta: Sinar Grafika, 2013), 13.
} 
are still very much felt. ${ }^{2}$ Based on the 2014 Central Bureau of Statistics (BPS) survey, data was obtained that the constraints faced by small businesses in 20 provinces were capital problems, namely $31 \%$ raw material, $26 \%$ competition, $17 \%$ production techniques, and $2 \%$ management. The data above shows that the problem of capital plays a crucial role in the development of the business sector in Indonesia. Therefore, it is deemed necessary to continue to improve capacity, especially for small businesses, to be able to access sources of funds from various financial sources to meet the need for capital.

Funding institutions are said to be alternative sources of financing because there are still many other financial institutions outside the financial institutions that can provide financial assistance, such as pawnshops, capital markets, banks, and so on. However, in reality, not all business actors can easily access each type of source of funds. ${ }^{3}$ The difficulty of obtaining these funds is caused by each of these financial institutions implementing provisions that cannot easily be met by those who need funds. ${ }^{4}$

The bank that has been widely known by the community turned out to be unable to meet the various needs of the funds needed by the community. ${ }^{5}$ The difficulty of small-scale entrepreneurs in accessing funds from banks is due to, among other things, the spread of uneven bank loans, the necessity of banks applying the principle of prudent banking, the necessity of debtors to surrender collateral, and limited bank capital capabilities themselves. Given the many obstacles to obtaining funds from the bank, financial institutions are one of the most important and potential alternative sources of funding that should be considered. ${ }^{6}$

In addition to acting as an alternative source of funding, financial institutions also have an important role in terms of development, namely accommodating and channelling people's aspirations and interests to play an active role in development. The aspirations and interests of the community in development (economy) can be realized if there are parties who facilitate it. Financing institutions as sources of financing can contribute in the form of financial assistance to grow and realize the aspirations and interests of micro,

2 Annisa PH, Dewi, Feronica, "Implementasi Peraturan Menteri Keuangan Nomor 18/PMK.10/2012 Tentang Perusahaan Modal Ventura Terhadap Usama Mikro Kecil dan Menengah", Privete Law 1, (2013): 27.

${ }^{3}$ Mireza Fitriadi \& Sinung Driyo Subanar, "Kedudukan Otoritas Jasa Keuangan Terhadap Perusahaan Modal Ventura Asing Dalam Melakukan Pembiayaan Secara Langsung di Indonesia", Journal of Legal Research 1, no. 2 (2014): 77-86, 77.

${ }^{4}$ Arni Utamaningsih, "Modal Ventura: Perubahan Paradigma Pendanaan di Indonesia dan Agenda Riset Masa Depan”, Polibisnis 6, 2 (2014): 29-38, 30.

5 Yuliana Panjaitan, Budiman Ginting, Ramli Siregar, "Aspek Hukum Perusahaan Modal Ventura Sebagai Salah Satu Lembaga Pembiayaan di Indonesia”, Transparency, Journal of Economic Law 3, no 2 (2014): 2

6 Safrina, "Peranan Modal Ventura sebagai Alternatif Pembiayaan Usaha Kecil dan Menengah”, Kanun Jurnal Ilmu Hukum 59, 15 (2013): 131-144, 131. 
small, and medium enterprises. ${ }^{7}$ With funding assistance from these financial institutions, it is expected that micro, small, and medium enterprises can overcome one of the common factors experienced, which is the capital factor. ${ }^{8}$

One financial institution that is a friend of small entrepreneurs is venture capital. In general, venture capital financing does not see guarantees of goods belonging to the Business Partner Company. The term "Venture Capital" comes from the English venture capital. In his book "Venture Capital Today," Tony Lorenz stated that venture capital is a Long term investment in high-risk capital, providing funds/venture capital aims, rather than interest or dividend income. ${ }^{9}$ Robert White defines venture capital as a provider of financing to establish and develop new ventures in technology and non-technology. ${ }^{10} \mathrm{~A}$ venture capital company is a business entity that carries out financing activities in the form of capital participation in a business partner company for a certain period. ${ }^{11}$

Venture Capital is theoretically a friend of a small and medium business in carrying out its business because Venture Capital provides investment, not in the form of loans or credit, but the form of capital investment. ${ }^{12}$ The government also seeks Venture Capital to become an alternative. ${ }^{13}$ Financing is shown to small or new companies that have the potential to grow and bright prospects, technology or non-technical aspects, or businesses that contain new breakthroughs. The company that finds difficulty in obtaining bank credit. ${ }^{14}$

However, in practice today, venture capital companies in carrying out their business experience a shift in characteristics. Venture capital finance

\footnotetext{
7 Nur Syamsiyah, Heriyanto, Dedi Suhendi, “Analisis Pembiayaan Bagi Hasil dan Pendampingan Manajemen Bagi Perkembangan Pasangan Usaha dalam Perspektif Ekonomi Islam”, Syi'ar Iqtishadi Journal of Islamic Economics, Finance and Banking 3, no. 1 (2019): 1-21, 2, DOI: http://dx.doi.org/10.35448/jiec.v3i1.5519.

8 Ari Rahmad Hakim Budiawan, "Model Pembiayaan Dalam Kemitraan Usaha Pada Perusahaan Modal Ventura Berdasarkan Peraturan Presiden Nomor 9 Tahun 2009 Tentang Lembaga Pembiayaan", GaneÇ Swara 9, no. 1 (2015): 70-79, 74.

${ }^{9}$ Lorenz, Venture Capital Today (Cambridge: Woodhead, Faulker, 1985), 2

${ }^{10}$ White Robert, What is Venture Capital and Leverege Buy Out Fund Investing (First Nasdaq Institute Seminary, 1990), 4

11 Munir Fuady, Hukum Pembiayaan (Dalam Teori dan Praktek) (Bandung: Citra Aditya Bakti), 111

${ }^{12}$ Nitaria Angkasa, "Peran Lembaga Pembiayaan Modal Ventura Dalam Pemberdayaan Usaha Kecil", DERIVATIF 10, no. 2 (2016): 73-81, 73, DOI: 10.24127/jm.v10i2.112.

13 Tami Rusli, "Prosedur Kemitraan Dan Proses Pembiayaan Perusahaan Modal Ventura Terhadap Perusahaan Pasangan Usahanya. (Studi Pada PT. Sarana Lampung Ventura)", Keadilan Progresif 5, no. 1 (2014): 50-70, 50.

${ }^{14}$ Abdulkadir Muhammad, Rilda Murniati, Aspek Hukum Lembaga Keuangan dan Pembiayaan (Bandung: Citra Aditya Bakti, 2000), 183.
} 
companies do this because of the demands of growing economic interests. ${ }^{15}$ The act of shifting characteristics carried out by venture capital finance companies aims to minimize the high risks that they will face. Venture capital companies in financing today are beginning to emphasize the guarantee aspect. The actions of a venture capital company that carries out financing by emphasizing this aspect of collateral are not by the characteristics of the venture capital company itself.

As much as $70 \%$ of the venture capital industry currently deviates from its main function, namely equity participation to business actors (PPU), especially beginner entrepreneurs. At present, the majority of the venture capital industry is engaged in providing loans and direct loans like banks. The Chief Executive Officer of the Non-Bank Financial Industry Supervisor of the Financial Services Authority or Otoritas Jasa Keuangan (OJK), Firdaus Djaelani, acknowledged the number of the venture capital company or nonbank business capital provider continued to shrink from year to year. The capital business for driving the development of new entrepreneurs in Indonesia is now only 70 companies, of which only 60 companies are active from 100 companies or $40 \%$ shrinkage. ${ }^{16}$

One thing that is very important and underlies this alternative thinking is that the role of venture capital has not been optimal, or it can be said that while it is not working. In practice, in Indonesia, venture capital companies carry out their business like banking. That until now, in general, venture capital companies practice more as credit providers as the usual practice of providing bank loans. All requirements and conditions requested for a business partner company (actually: a debtor) are like a bank in giving credit.

\section{B. Discussion}

It is expected that with legal reform, venture capital financing institutions will create a venture capital industry in Indonesia that reflects the characteristics of venture capital through funding support activities in the start-up industry, including the creative economy. In addition, it can reduce the mismatch between funding sources and the characteristics of the business activities of the Venture Capital Company. It is also expected to have access to funding for the development of business actors engaged in the creative economy and micro, small, and medium enterprises or Usaha Mikro, Kecil dan Menengah (UMKM).

\footnotetext{
15 Sihabudin, "Reevaluasi Pembiayaan Perusahaan Melalui Modal Ventura di Indonesia", Arena Hukum 9, no. 2 (2016): 289-306, 289, DOI https://doi.org/10.21776/ub.arenahukum.2016.00902.8.

16 http: www.amvi.or.id, As many as $70 \%$ of the venture capital industry currently deviates from its main function, equity participation to business operators
} 
The venture capital mechanism, in principle, is a process that describes the flow of investment, which starts from the entry of investors by forming a pool of funds, the financing process at a partner company, until the withdrawal process of the investment (divestment). As explained above, in essence, venture capital is a pool of funds originating from investors and is managed professionally to be invested in companies that need capital.

The role of law as a means of social control to create order and peace in people's lives must not be separated from the philosophy of Pancasila, which requires the achievement of social justice for all Indonesian people. This provision is further specified in article 33 and article 27 (2) of the 1945 Constitution, which essentially states that the role of law is not merely maintaining order, security and stability of the community in the sense of keeping the peace at all events at any price, but also directed on the ideals to achieve the welfare of the Indonesian people. However, the development of Indonesian national law must be based on values derived from Indonesian culture itself. Not necessarily, values from outside are annexed in such away. Based on such conditions, legal development in developing the concept of venture capital financing institutions and UMKM as a Business Partner Company includes the following:

First, the direction of the legal renewal of the Venture Capital Financing Institution must reflect the management of venture capital companies in accordance with existing best practices. In the United States and European countries that have become comparative studies, the existence of venture capital financing institutions is presented to finance capital-intensive, up-todate companies in the field of high-tech development, and individuals with high risks and high opportunities to gain profits within a certain period. Likewise, Britain, the Netherlands, South Korea, Taiwan, Japan, and India. Generally directed at companies based on individual ownership, and Venture Capital Companies themselves are private companies, or at least the largest shares of Venture Capital Companies are privately owned, only a small portion is controlled by the government.

Apple Computer, Kentucky Freid Chicken, Wang Computer, Daz Ice Cream, Tierack, Garfunkels, Sock Shop, and Genentech are just a few of the growing companies with financing sourced from Venture Capital Companies in the American continent. While Japan is developing a company engaged in the field of robotics, the electronics and semiconductor industries are growing rapidly in Taiwan with financial support from the Venture Capital Company. Although not a few also there are failures of Business Partner Companies from Venture Capital Companies, for example, Victor Technology, Osborne Computer, Vector Graphics, and Pizza Time Theater. However, the success of a Business Partner Company is far more interesting to be an example of an ideal model of applying a Venture Capital Company to a Business Partner Company in these countries. 
Second, the law as an institution and the process needed to realize the enactment of the law in reality intended is the existence of UMKM as a Business Partner Company for Venture Capital Companies, and Venture Capital Companies as sources of financing for UMKM are business institutions that are legally recognized for their existence, or at least UMKM is a type of business that is de facto present to run a certain type of business that economically impacts the surrounding community. Not merely an effort in the context of increasing income and economy for its owner, but there is truly a belief that there is a good intention of the owners of UMKM to make the community not just a target for marketing its commodity goods, but also to make the community as a business partner to prosper together. Companies engaged in the field of high-tech development as the Business Partner Company in the United States or other advanced technology countries have barely developed in Indonesia, so UMKM, with their character in the Indonesian model, is the ideal choice as a business partner for venture capital companies.

Third, order as the main objective of the law requires regulations that guarantee certainty and business continuity between the Venture Capital Company and the Business Partner Company. This certainty is regulated by the mechanism of agreement between the Venture Capital Company and MSME as a Business Partner Company. However, in addition to being bound by clauses regulated in legal relations between Venture Capital Companies and Business Partner Companies in the legislation governing Venture capital financing institutions, they are also generally subject to the general provisions of the contractual conditions stipulated in the 1320 Civil Code as a subjective requirement and objective, which if not fulfilled can be cancelled or requested to be cancelled by one of the parties.

Fourth, as a renewal tool to ensure the implementation of legal order in the development of Venture Capital Companies and Business Partner Companies, the choice of UMKM as a Business Partner Company is a wise choice. However, it should not be closed to providing financing to companies other than UMKM, high-tech and legal entities as a limited liability company. The transitional social and cultural conditions of the Indonesian people make this choice a way of carrying out the obligations of the state to protect and provide financing solutions for UMKM that are always constrained by capital and management.

Fifth, to ensure that changes occur in an orderly (regular) manner in the development of Venture Capital Companies and Business Partner Companies, the law plays a role through the assistance of legislation as the most rational and fast way compared to other legal development methods such as jurisprudence and customary law. Therefore, the drafting of legal reform regulations for venture capital financing institutions must pay attention to 
various aspects (legal, economic, social, and others) so that the law becomes effective.

In connection with the management of venture capital companies that have a strategic role as alternative financing for UMKM in Indonesia, so the regulations in the legal reform of venture capital financing institutions must be prepared as well as possible.

Based on the development law theory presented by Mochtar Kusumaatmadja, the legal reform of venture capital financing institutions is expected to encourage improvements in the governance of government venture capital companies in Indonesia. Some things that need to be done in the framework of legal reform of venture capital financing institutions as a political policy of state finance, among others by:

a. Improving the arrangement of the implementation of venture capital financing institutions to reduce the potential for redundancy, overlapped, and counterproductive. The arrangement is related to:

1) More detailed regulations regarding the implementation of venture capital must be established, especially those governing procedural contracts for venture capital financing agreements between venture capital companies and partner companies and their financing procedures based on the characteristics of venture capital so that the practice of venture capital financing does not approach banking credit activities. This is to change that venture capital as alternative financing but can be used as the main financing for UMKM. Basically, according to the opinion of the author on this site, one of the justification reasons why venture capital has changed from financing/inclusion in the form of equity to financing in the form of credit, considering that if venture capital financing must be in the form of equity, then that means financing can only be done to companies a business partner in the form of a Limited Liability Company (PT). According to Article 1, Paragraph 1 of the Regulation of the Financial Services Authority Number 34/POJK.05/2015 Regarding Business Licensing and Institutional Venture Capital Companies, stated that Venture Capital Business is a financing business through capital participation and/or financing for a certain period in the context of developing a business partner or debtor. Furthermore, Article 2 POJK Number 34 the Year 2015 Concerning Business Licensing and Institutional Venture Capital Companies states that the form of the business entity must be in the form of a limited liability company, cooperative, and limited partnership. Thus the alliance of people may get venture capital financing facilities other than companies in the form (PT) and cooperatives. Therefore, the provisions, as mentioned above, can also serve as a legal basis for establishing a venture capital financing model that does not merely require equity participation. However, also in 
other instruments, as needed, because venture capital or venture capital is narrowly capital that is invested in businesses that carry risks, both in equity capital investment, convertible bonds, and financing with profit sharing.

2) Venture capital industry business activities, that equity participation activities have a fairly high level of risk and face the times. Therefore, alternative business activities are needed such as providing working capital for UMKM in the productive sector, providing advisory services and fee-based business activities and, venture capital companies can expand the business into the field of financial technology (fintech), which can help the industry venture capital earns sustainable periodic income (sustainable income) to run the company's business while awaiting the return from the distribution of equity participation. However, these other activities are additional activities. The Venture Capital Company continues to give its main attention to increasing the distribution of equity participation activities as a core business so that the capital requirements for UMKM that are oriented towards entrepreneurship and innovative products can be met.

3) The divestment process policy for the venture capital industry also needs to be updated. Currently, divestments are generally carried out by way of resale to Business Partner Companies (PPU) or through an initial public offering (IPO) on the Indonesian capital market. In order to improve the divestment process by transferring to strategic investors by looking at the characteristics of UMKM business actors financed by the Venture Capital Company. Furthermore, it is necessary to study related to the acceleration board in the Indonesian capital market as a place for IPO for UMKM entrepreneurs in Indonesia as well as an alternative means of divestment of shares for a venture capital company in its business partner company (PPU) due to resale through an initial public offering (IPO) on the Indonesian capital market with very rigid and burdensome requirements and documentation for Business Partner Companies. Through the Micro, Small, and Medium Enterprises development program, it will enter the capital market (incubator), and venture capital companies can act as partners for UMKM in the Indonesian capital market.

4) It is strengthening venture capital industry capital. At present, the capital requirements for the establishment of venture capital are 10 billion IDR for national private Venture Capital Company or Perusahaan Modal Venture (PMV) and 30 billion IDR for joint venture PMVs. In order to increase the capacity of the venture capital industry in developing its business activities, it is necessary to conduct a study to strengthen the capital of the venture capital industry by 
increasing capital requirements for the establishment of venture capital.

5) Renewal of supervision, which is on-site supervision in the form of Direct Inspection. With the enactment of Law Number 21 the Year 2011 regarding the Financial Services Authority on November 22, 2011, the task of supervision of the Venture Capital Company or Sharia Venture Capital Company is transferred to the Financial Services Authority from December 31, 2012. Of course, a legal basis is required for the Service Authority Finance in carrying out its functions and authorities to oversee Venture Capital Companies or Sharia Venture Capital Companies in the form of Direct Examination of the business activities of venture capital companies so that the implementation of venture capital company business activities is in accordance with its establishment permit, so that venture capital companies do not in practice provide credit as carried out nowadays.

b. Establishment of a legal entity managing funds (venture fund) by a Venture Capital Company.

Separate the operation and management of venture capital funds, the structure of one layer of venture capital activities is contrary to best practices, in which ownership and management of capital are separated. This has hampered the ability of venture capital companies to raise funds from investors. By allowing management companies to be separated from venture capital companies, the use of management expertise will be facilitated. With this venture fund, it is expected to raise funds from professional investors such as insurance companies, pension funds, and individual investors with a longer tenor, so that Venture Capital Companies can provide access to capital for businesses and UMKM that are oriented towards entrepreneurship and products innovation at the beginning of its establishment. Other funding sources that need to be studied further are funding sources collected through crowdfunding. Crowdfunding has begun to develop in several countries, including the United States, Britain, Singapore, India, and Malaysia.

c. Implementation of Sharia system

Venture capital financing instruments are actually very close to Islamic based financing. By looking at the definition and characteristics of venture capital, and connecting with five types of sharia contracts, namely (1) deposit/deposit system (Al Wadiah), (2) profit sharing (Syirkah), (3) Sale and Purchase (At Tijarah), (4) rent (Al Ijarah), and (5) services/fees (Al-Ajr wal umullah), the venture capital venture company has legal similarity with the syirkah (profit sharing) contract. By looking at the understanding, terms and laws of syirkah, from six types/forms of syirkah, namely syirkah al-'inan; syirkah al-mufawadhah; syirkah alabdaan; syirkah al-wujuh; and syirkah al-mudharabah, venture capital 
companies in terms of the contract/agreement have in common with syirkah al-inan, namely an agreement to cooperate to do joint work by sharing profits or losses together. However, in reality, what is happening in Indonesia is the application of fixed revenue-sharing or minimum profit-sharing from outstanding financing that adopts banking patterns with flat routes or effective rates due to various obstacles encountered. Venture capital companies and Islamic venture capital must be able to apply a pattern of pure sharia revenue sharing, which is based on profit and loss sharing that allows for fluctuations.

Looking at the conditions that occur in the venture capital industry, it is necessary to make policy breakthroughs so that the venture capital industry in the future will be able to develop along with the development of other financial industries and be able to be the driver of the birth of new entrepreneurs in Indonesia. In realizing the venture capital development policy, OJK as a venture capital financing regulator is certainly not possible to be alone but must work with other stakeholders such as the Coordinating Ministry for Economic Affairs, Ministry of BUMN, Directorate General of Tax, Ministry of Cooperatives and UMKM, Creative Economy Agency KADIN, a venture capital industry player, and several universities that have economic incubators. Of course, the OJK also needs political support from the House of Representatives.

\section{Conclusion}

The concept of legal reform of venture capital financing institutions as alternative financing for micro small and medium enterprises is carried out using the need for better regulation related to the implementation of venture capital financing institutions to reduce the potential for redundancy, overlapped, and counterproductive. As a related regulation: expansion of venture capital industry business activities, the policy of the divestment process for the venture capital industry also needs to be updated, strengthening the capital of the venture capital industry, more detailed technical regulations regarding the implementation of venture capital should be established, especially those governing procedural contracts for capital financing agreements. Venture and supervision need to be done on-site supervision in the form of a Direct Inspection, the establishment of a legal entity managing funds (venture funds) by a venture capital company applying a pure sharia profit-sharing pattern. With the legal reform of venture capital financing institutions, a venture capital industry in Indonesia will be created that reflects the characteristics of venture capital through funding support activities in the start-up industry, including the creative economy. In addition, it can reduce mismatches between funding sources and the characteristics of venture capital company business activities. 


\section{Recommendation}

It is expected that the government supervises the business activities of venture capital companies so that the implementation of venture capital company business activities is in accordance with its establishment permit, so that venture capital companies do not provide loans in practice as is currently practised and a revision of the Financial Services Authority Regulation concerning Institutional Capital Venture Companies related to the expansion of venture capital industry business activities, the policy of the divestment process for the venture capital industry also needs to be renewed, strengthening the capital of the venture capital industry, it is necessary to establish regulations regarding the implementation of venture capital in more detail, especially those governing procedural contracts for venture capital financing agreements and the need for supervision is conducted on-site supervision in the form of direct inspection.

\section{References}

Angkasa, Nitaria. "Peran Lembaga Pembiayaan Modal Ventura Dalam Pemberdayaan Usaha Kecil”, DERIVATIF 10, no. 2, 2016: 73-81, DOI: $10.24127 / j m . v 10 i 2.112$.

Budiawan, Ari Rahmad Hakim. "Model Pembiayaan Dalam Kemitraan Usaha Pada Perusahaan Modal Ventura Berdasarkan Peraturan Presiden Nomor 9 Tahun 2009 Tentang Lembaga Pembiayaan”, GaneÇ Swara 9, no. 1, 2015: 70-79.

Fitriadi, Mireza., Subanar, Sinung Driyo. "Kedudukan Otoritas Jasa Keuangan Terhadap Perusahaan Modal Ventura Asing Dalam Melakukan Pembiayaan Secara Langsung di Indonesia", Journal of Legal Research 1, no. 2, 2014: 77-86.

http:www.amvi.or.id, As many as $70 \%$ of the venture capital industry currently deviates from its main function, equity participation to business operators.

http:www.bps.go.id, the constraints of small business entrepreneurs.

Lorenz. Venture Capital Today. Cambridge: Woodhead, Faulker, 1985.

Muhammad, Abdulkadir., Murniati, Rilda. Aspek Hukum Lembaga Keuangan dan Pembiayaan. Bandung: Citra Aditya Bakti, 2000.

Panjaitan, Yuliana., Ginting, Budiman., Siregar,. Ramli. "Aspek Hukum Perusahaan Modal Ventura Sebagai Salah Satu Lembaga Pembiayaan di Indonesia", Transparency, Journal of Economic Law 3, no. 2, 2014: 1-7.

PH, Annisa., Dewi., Feronica. "Implementasi Peraturan Menteri Keuangan Nomor 18/PMK.10/2012 Tentang Perusahaan Modal Ventura Terhadap Usama Mikro Kecil dan Menengah", Privete Law 1, 2013.

Robert, White. What is Venture Capital and Leverege Buy Out Fund Investing. First Nasdaq Institute Seminary, 1990. 
Rusli, Tami. "Prosedur Kemitraan Dan Proses Pembiayaan Perusahaan Modal Ventura Terhadap Perusahaan Pasangan Usahanya. (Studi Pada PT. Sarana Lampung Ventura)", Keadilan Progresif 5, no. 1, 2014: 50-70.

Safrina. "Peranan Modal Ventura sebagai Alternatif Pembiayaan Usaha Kecil dan Menengah", Kanun Jurnal Ilmu Hukum 59, 15, 2013: 131-144.

Sihabudin, "Reevaluasi Pembiayaan Perusahaan Melalui Modal Ventura di Indonesia", Arena Hukum 9, no. 2, 2016: 289-306, DOI https://doi.org/10.21776/ub.arenahukum.2016.00902.8.

Sunaryo. Lembaga Hukum Pembiayaan. Jakarta: Sinar Grafika, 2013.

Syamsiyah, Nur., Heriyanto., Suhendi, Dedi. "Analisis Pembiayaan Bagi Hasil dan Pendampingan Manajemen Bagi Perkembangan Pasangan Usaha dalam Perspektif Ekonomi Islam", Syi'ar Iqtishadi Journal of Islamic Economics, Finance and Banking 3, no. 1, 2019: 1-21, DOI: http://dx.doi.org/10.35448/jiec.v3i1.5519.

Utamaningsih, Arni. "Modal Ventura: Perubahan Paradigma Pendanaan di Indonesia dan Agenda Riset Masa Depan”, Polibisnis 6, 2, 2014: 2938 . 